\title{
Editorial: Introduction to the First Issue of Management Accounting Frontiers
}

\author{
V. G. Sriharan ${ }^{\mathrm{a}}$, Michael S. C. Tse ${ }^{\mathrm{b}}$ \\ ${ }^{a}$ University of Adelaide, Australia \\ ${ }^{\mathrm{b}}$ Holmes Institute, Australia
}

On behalf of the Editorial Board, we are delighted to present the inaugural issue of Management Accounting Frontiers (MAF). As the flagship research journal of the Institute of Certified Management Accountants, MAF strives to facilitate the development of new and cutting-edge research themes in management accounting by encouraging open communication between academicians and practitioners. To achieve its objective, MAF welcomes not only empirical studies but also high quality theoretical works including literature reviews and normative articles that offer novel and fresh perspectives to issues important to management accounting research and practice.

The three articles featured in this issue reflect the broad range of interests of this journal. The first article, by G. K. Laing, studies the intensity of the contribution management accounting innovations have had in the academic literature. Based on an approach derived from seismic measurement of earthquakes, a new measurement model is developed and applied in the measurement of intensity of contributions of Balanced Scorecard, Activity Based Cost Accounting and Lean Accounting in literature.

The second article, by M. So, explores the issue of recognising intellectual capital in organisations. After a review of extant intellectual capital valuation models, the author proposes a framework of intellectual capital valuation and reporting based on organisational capabilities.

The third article, by C. A. Tilt, M. Xydias-Lobo, F. Rodricks, and G. Reynolds, presents a comparative investigation of perceptions of Integrated Reporting in Australia and Hong Kong. The authors examine the perceptions of readiness and acceptance of Integrated Reporting in Australia and Hong Kong through interviewing accounting professional 
Management Accounting Frontiers 1 (2018) 1 - 2

associations and firms regarding their awareness of and attitudes towards Integrated Reporting.

The publication of this issue is the result of considerable efforts of the members of MAF Editorial Board. Their generous support is invaluable.

We hope you will enjoy reading our first issue and find these articles useful to stimulate your research and practice in management accounting. 